\title{
De Coriolanos e Coiranas: a trajetória cênica e fílmica do ator Lorival Pariz
} Of Coriolanos and Coiranas: the scenic and filmic
trajectory of the actor Lorival Pariz

Luiz Humberto Martins Arantes ${ }^{1}$ 


\section{Resumo}

Este artigo pretende refletir acerca da trajetória do ator Lorival Pariz (1934-1999), profissional de teatro e cinema, que participou de relevantes montagens e filmagens da história do teatro e do cinema nacional. Podem ser citadas: As Três Irmãs, Um Grito Parado no Ar, O Dragão da Maldade Contra o Santo Guerreiro e O País dos Tenentes. Pretendemos olhar as escolhas de Lorival Pariz à luz da história, confrontando as relações entre atuação/teatro/cinema/história. Procurando, assim, escrever uma história do espetáculo, valorizando sua trajetória, suas escolhas dramatúrgicas e seu ofício de ator.

Palavras-chave: Lorival Pariz; teatro; cinema; ator; personagem.

\section{Abstract}

This article intends to reflect on the trajectory of the actor Lorival Pariz (19341999), theater and cinema professional who participated in relevant montages and filming of the history of the theater and the national cinema. They can be cited: As Três Irmãs, Um Grito Parado no Ar, O Dragão da Maldade Contra o Santo Guerreiro and $O$ País dos Tenentes. We intend to look at Lorival Pariz's choices in the light of history, confronting the relations between acting / theater / movie theater/ history. Trying to write a story of the show valuing its trajectory, its dramaturgical choices and its acting profession.

Keywords: Lorival Pariz; theater; movie theater; actor; character 
A estreia, em 2016, da telenovela Haja Coração, no horário das dezenove horas, ensaiou trazer de volta algumas lembranças televisivas, primeiro porque não passava de um remake da antiga Sassaricando, trama do final da década de 1980, que ambientava as confusões dos personagens Aparício Varella e Teodora, vividos por Paulo Autran e Tônia Carrero. Mas também permitiu o retorno do personagem Boris Zaidan, então vivido pelo ator Lorival Pariz, artista de teatro, cinema e televisão de longa trajetória.

Este artigo objetiva percorrer a trajetória deste ator, localizar suas escolhas teatrais e cinematográficas, compreender seu modo de atuação, composição de personagens e o impacto de seu fazer artístico no contexto histórico brasileiro pós década de 1960, principalmente ao longo da ditadura civil-militar. Momento de censura e restrição das liberdades, mas que, mesmo assim, alguns conseguiram atuar nas brechas do sistema.

Analisar a trajetória cênica de Lorival Pariz é também jogar luzes acerca de como vem sendo escrita a história do teatro brasileiro. Os recortes propostos, muitas vezes, preferem ressaltar diretores, dramaturgos, suas obras e biografias, deixando um pouco de lado uma possibilidade de história do teatro por meio do estudo do trabalho dos atores. Assim, tem se deixado para as biografias cumprirem esse papel, que, muitas vezes, prioriza o elogio e o aplauso fácil ao longo de uma vida inteira. Nesse sentido, há que se retomar a necessária escrita de uma história do teatro, que sublinhe também a importância de atores e atrizes e seus processos de criação e a inter-relação com seu tempo vivido.

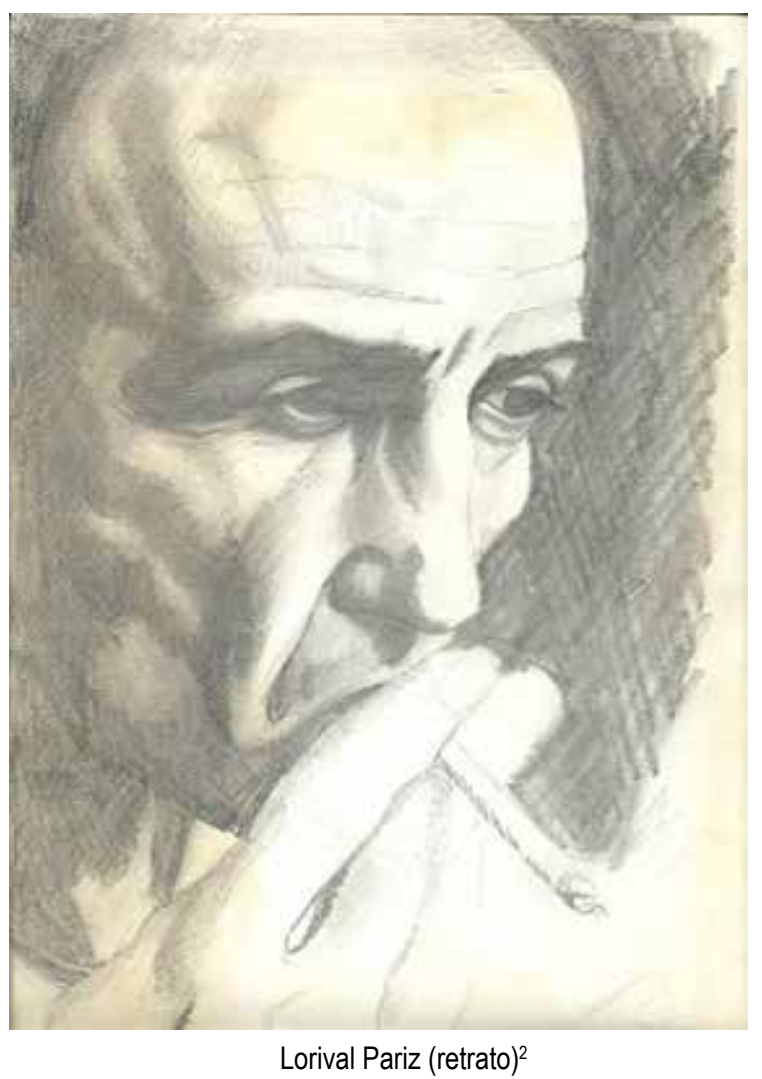

${ }^{2}$ Fonte: https://www.facebook.com/478506518930320/photos/a.506542889460016.1073741826.478506518930320/626093524171618/?type=3\&theater. 0 acesso a este retrato só foi possível graças à indicação de Yma Marton, ex-aluno de capoeira de Pariz em Los Angeles. 
A centelha inicial para este artigo foi a presença de Lorival Pariz em Uberlândia/ MG, a partir de 1994, sabe-se, hoje, que sua vinda para Minas estava associada à criação do Curso de Artes Cênicas, da Universidade Federal de Uberlândia. A criação da graduação trouxe muita expectativa, pois se difundiu a ideia de que a universidade teria uma companhia de teatro estável e que a vida cênica da cidade teria alterações significativas. Havia no ar muita expectativa com o início de um grande projeto no interior do país. Ele viveria os últimos dias de sua vida na cidade mineira, onde exercia as funções de professor assistente no curso de Artes Cênicas. Aposentou-se das atividades docentes em 1998, vindo a falecer no ano seguinte.

A primeira e única montagem de Pariz como ator, na cidade, reforça o impacto desse projeto do curso, foi El dia que me queiras de José Ignácio Cabrujas, com direção de Antônio Mercado3, texto que tematizava as crises, avanços e recuos da esquerda latino-americana e seus distantes planos de uma revolução. A peça narra a iminente visita do ilustre cantor Carlos Gardel e, ao mesmo tempo, mostra a família Ancízar vivendo sua decadência e uma intensa crise afetiva, pois uma das irmãs, Maria Luiza, quer vender a casa para partir com seu noivo.

Mas, para entender melhor esse destino final do ator Lorival Pariz, há que se retornar ao final da década de 1960, às suas primeiras montagens, e compreender as escolhas estéticas que foi fazendo ao longo da vida, em teatro e também em cinema.

O Período pós 1964 foi de muitas dificuldades para o campo do pensamento progressista no Brasil. As universidades e os intelectuais, de uma forma geral, sofreram com os expurgos e os exílios. Alguns setores da imprensa, não alinhados ao golpe, tiveram que se reinventar para fugir à censura e ao cerceamento à liberdade de imprensa.

Mas foi no campo da produção cultural e artística que as ações do golpe e do Al-5, de 1968, provocaram os maiores estragos. Foram muitos as aposentadorias forçadas, os exílios, culminando com prisões e torturas. Fatos estes recentemente expostos pelos relatórios da Comissão Nacional da Verdade (CNV) ${ }^{4}$.

Muitos intelectuais e artistas foram forçados ao exílio ou se auto exilaram, enquanto outros escolheram ficar e, na medida do possível, construíram a resistência por meio das fissuras que a prática política construía naquele contexto tão conturbado.

No caso do teatro e da dramaturgia, muitos criadores optaram pela criação de textos teatrais alegóricos, que não tocavam diretamente em temas gritantes da realidade brasileira. Mas sim, por obras que por meio de metáforas e narrativas ambientadas em outros contextos, criticavam situações de falta de liberdade, censura e tortura. Assim, conseguiam, não totalmente, driblar os censores de textos e peças ${ }^{5}$.

\footnotetext{
${ }^{3}$ No elenco: Beatriz Bologna, Edmar Ferretti, Heleno Prestes, Lorival Pariz, Miriam Mehler e outros.

${ }^{4}$ http://cnv.memoriasreveladas.gov.br/

${ }^{5}$ Apenas para mencionar alguns: Ponto de Partida (Gianfrancesco Guarnieri), Arena Conta Zumbi (Guarnieri e Augusto Boal) e Calabar (Chico Buarque).
} 


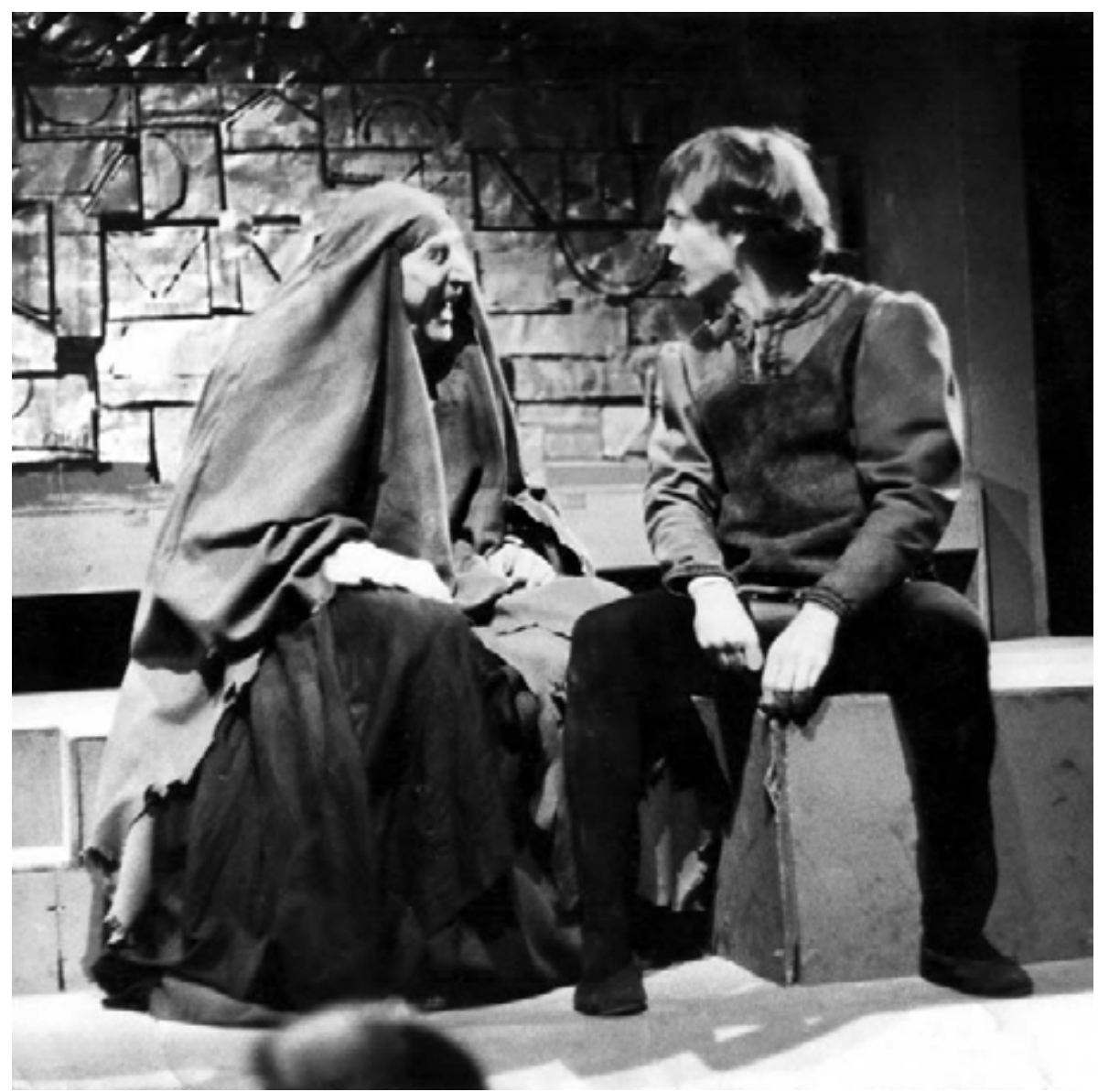

Pariz (Semprônio) e Ziembinski (Celestina) em 1969

Dentre os artistas teatrais que ficaram no Brasil pós-golpe, e que, por aqui, empreenderam suas trajetórias, - ora resistindo no grito, ora discretamente atuando nas brechas, - pouco se fala da figura de atores e atrizes que enfrentaram os dias difíceis. Não foram poucos os atuadores que escolheram o ofício da interpretação teatral como resistência, muitas vezes, fora das redes de televisão.

As escolhas de Lorival Pariz o levaram para o caminho de sempre, que é dialogar com o contexto à sua volta. A sua estreia nos palcos de São Paulo foi, simplesmente, pelas mãos do conhecido Ziembinski . O então renomado diretor polonês de Vestido de Noiva, de 1943 estava, em 1969, tentando colocar em cena a peça A Celestina, um clássico latino americano de Fernando de Rojas.

O ano de 1968 não era dos melhores para o projeto, havia toda uma expectativa de que mudanças estavam para acontecer, além de toda a efervescência do engajamento teatral dos anos anteriores, mas a imposição do Ato Institucional n. 5 (Al-5) caiu como um balde de água fria. Todo aquele projeto de vanguardas teatrais desenvolvido nos anteriores foi substituído, no campo teatral, pelo instinto de sobrevivência, num contexto de censura e perseguições políticas. Assim, apostar numa montagem teatral com dimensões políticas era um ato de coragem e também de imenso risco financeiro.

${ }^{6}$ Fonte: Cardoso, 2009, 79.

${ }^{7}$ Zbigniew Marian Ziembinski (1908-1978), polonês radicado no Brasil, ator e diretor de teatro, cinema e televisão. 
Dirigida por Ziembinski e traduzida por Eudynir Fraga, a montagem de A Celestina foi tudo isso, mas não foi um sucesso de público e nem de crítica. Por um lado, foi rejeitada por suas opções estéticas, pois julgavam o diretor já ultrapassado diante das últimas experiências estéticas da década de 1960, e, por outro, entendiam que a concepção cênica escolhida não era tão contundente na crítica ao regime militar.

Mas a peça foi realizada e esteve em cartaz por um mês em São Paulo, teve apoio de verba pública e reuniu um elenco de mais de vinte profissionais. Dentre eles estava Lorival Pariz, interpretando Semprônio. O espetáculo e parte do elenco receberam de Sábato Magaldi o seguinte comentário:

Era necessário também um elenco experimentado, ao menos para os papéis principais. E, para não admitir logo que Thais Moniz Portinho e Adilson Wladimir não são adequados para interpretar Melibea e Calisto [...] ressalve-se que não têm maturidade. Conseguem salvar-se Lorival Pariz (um ótimo Semprônio), Myra Rosani e Maria do Carmo Bauer. (Magaldi, in: Jornal da Tarde, 04 dez.1969).

Para quem estava começando sua carreira em São Paulo, não era má ideia iniciar sendo dirigido por Ziembinski e já receber um elogio de Sábato Magaldi. No restante do elenco, nomes que iriam ter uma longa trajetória no teatro brasileiro, tais como: Everton de Castro e o maestro Diogo Pacheco (Lins, 2009, p. 85).

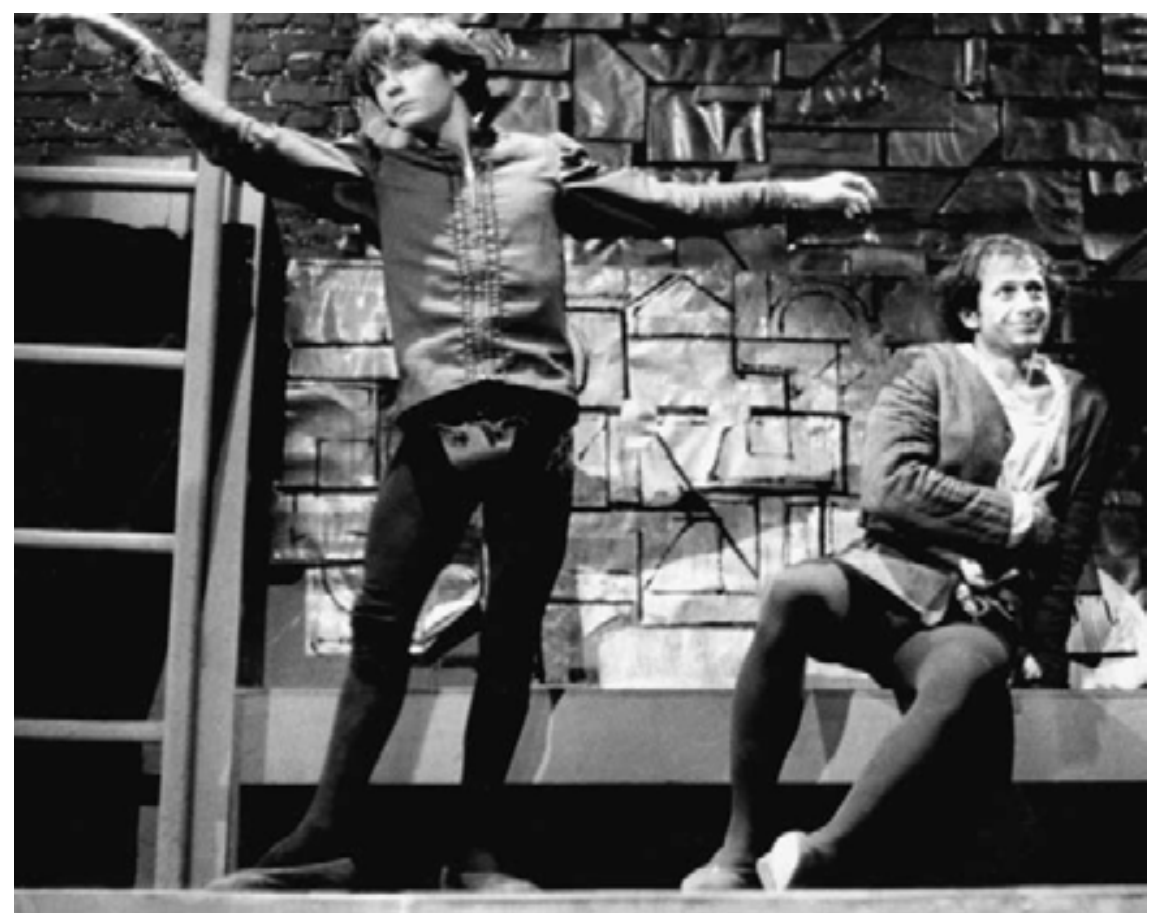

Everton de Castro e Pariz (sentado) em A Celestina, $1969^{8}$

Na sequência de seu trabalho, Pariz iria se encontrar com um dos principais autores brasileiros das décadas de 1960 e 1970: José Vicente. Após ter alcançado relativa projeção coma montagem de $O$ Assalto, Vicente pretendia estrear Os Convalescentes, que estreou ainda em 1969.

\footnotetext{
${ }^{8}$ Fonte: Cardoso, 2009, 79.
} 
Num Brasil e numa América Latina conturbados politicamente, José Vicente propõe um enredo que colocava o dedo em algumas feridas políticas. Segundo o crítico Jeferson Del Rios, era uma síntese das consciências perturbadas do período:

\begin{abstract}
José Vicente coloca em cena quatro pessoas insatisfeitas com o ambiente de opressão e repressão em que vivem. O mais velho, é o liberal típico, professor universitário que influenciou muitos pelo modelo pacifista. Sua mulher, rica, vive sem esperanças de superar os limites de classe e formação. Ao final, tenta romper o círculo de ferro com um gesto corajoso e inútil. O terceiro elemento desse inventário político-existencial é o anarquista que se debate na frustração de não conseguir novos instrumentos de luta. O quadro se completa com a jovem na luta armada. A ação é acelerada pelo fato do marido dela estar preso e ela pretender resgatá-lo. O desalentador na situação de todos é a constatação de que seu romantismo está condenado ao fracasso. Não interfere concretamente nos acontecimentos. Convalescentes da festa que acabou giram em círculos; e José Vicente tem a coragem de se situar entre eles. É uma das peças mais honestas do teatro brasileiro dos últimos tempos. (Del Rios, 2010, p. 15).
\end{abstract}

O espetáculo teve a direção de uma mulher, Gilda Grillo, algo, infelizmente, raro naquele período e a cenografia de Marcos Flaksman, que concebeu a cena como se fosse uma gaiola. A diretora foi elogiada à época por ter concebido uma direção seca e arrojada, sendo elogiada pela direção de atores. Pariz teve ao seu lado, neste trabalho, novamente, Everton de Castro e Norma Bengel, todos jovens na ocasião e sem a fama que a televisão iria lhes proporcionar nas décadas seguintes. A presença de cena de Pariz foi reconhecida, mas também criticada: [...] ator sóbrio que trabalha muito o que faz, deveria ser mais natural nos movimentos em cena (Del Rios, 2010, p. 16). 


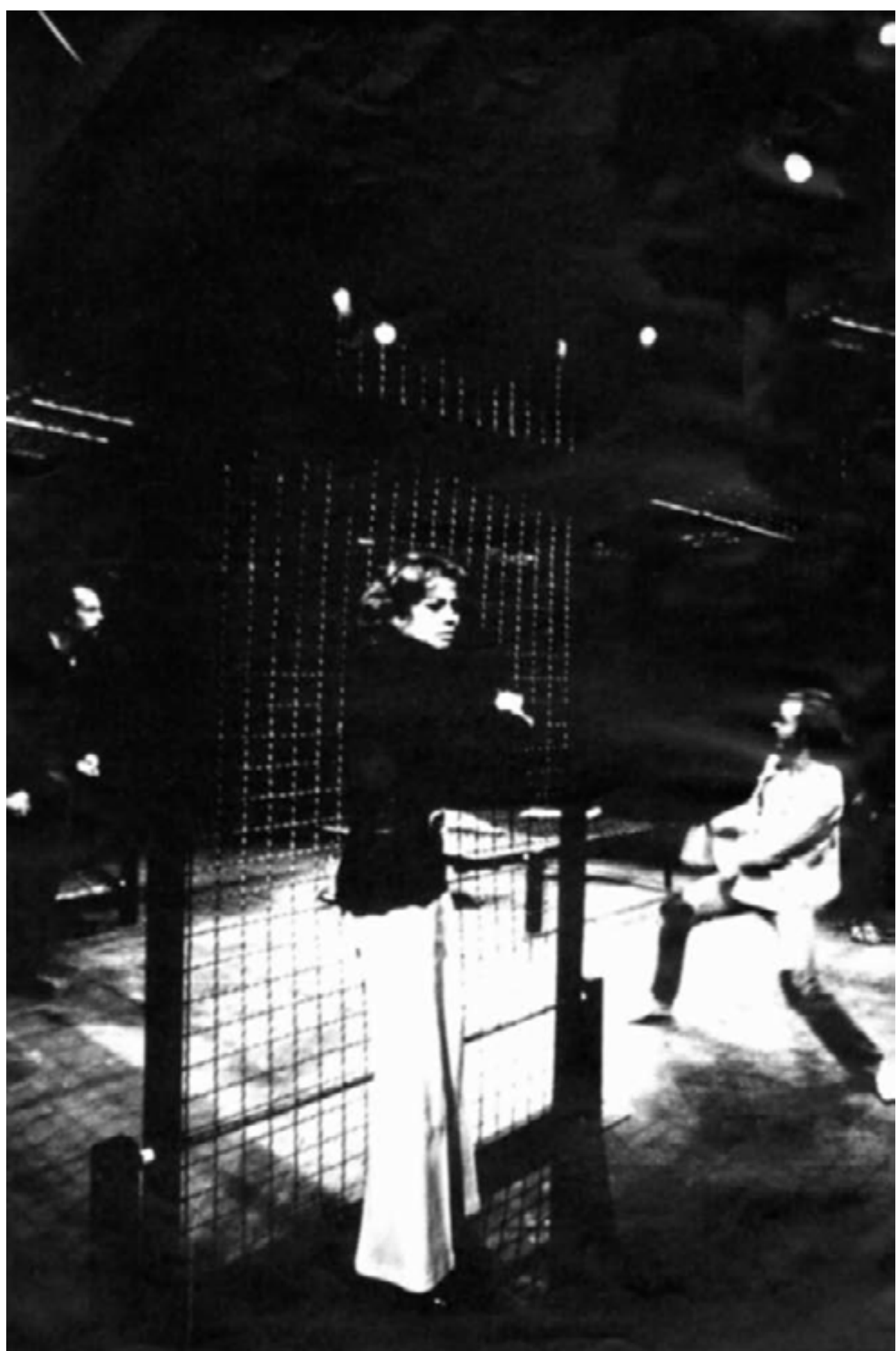

Pariz, Norma Bengel e Everton de Castro em Os Convalescentes ${ }^{9}$

O ator Everton de Castro, que também participou da montagem, em depoimento, lembra o seu forte teor político:

Mas a peça de José Vicente era contundente porque contava a verdade das prisões políticas. As personagens descreviam as torturas com todos os detalhes. Apesar do clima pesado foi importante ter participado dessa importante denúncia. (Cardoso, 2009, p. 91)

\footnotetext{
${ }^{9}$ Fonte: Cardoso, 2009, 84.
} 
Mas o que merece destaque é que Pariz, nesse início de carreira teatral, em fins da década de 1960, demonstra escolhas muito maduras, são indicadas não apenas montagens aleatórias, mas sim opções políticas e bastante engajadas num país que vivia uma ditadura civil-militar. As pessoas ao seu lado sinalizam para um fazer teatral coletivo, muito ligado à atuação política, sublinhando que o teatro não estava descolado daqueles difíceis tempos.

Nesse início da década de 1970, impossível não lembrar também da experiência de Lorival Pariz, com o Teatro Oficina, que ocorreu durante o ano de $1972^{10}$, na montagem de As Três Irmãs, do russo Anton Tchekov, na qual Pariz interpretou o personagem Verchinin, um militar amigo da família. Por ser mais velho, Verchinin acompanhou o crescimento das três irmãs, mas é um homem que aparenta infelicidade conjugal sem seu casamento.

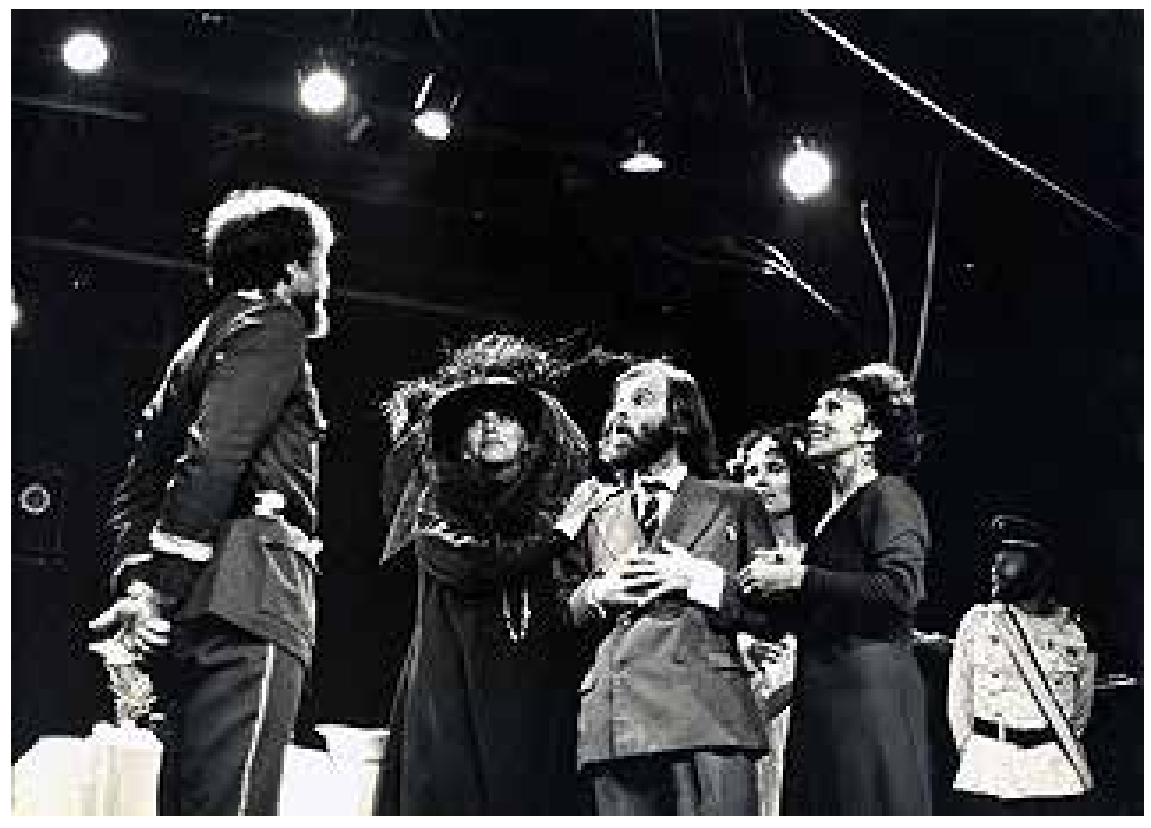

Pariz (costas) em As três irmãs, Teatro Oficina, 1972.11

As Três Irmãs foi encenada, pela primeira vez, em novembro de 1972, a peça atualizava o texto russo no Brasil, mas também prenunciava a própria crise do Teatro Oficina, que começava a se fragmentar em virtude de diferenças estéticas, mas que também via alguns de seus membros serem ameaçados com a possibilidade da prisão e do exílio. O que não demorou a acontecer, pois, logo depois, em 1974, José Celso iria para Portugal.

A ambientação da peça de Tchekov, que narra a angústia de uma vida provinciana e o latente desejo de mudança para um grande centro urbano, dialogou perfeitamente com o momento político brasileiro. Pariz participou desse processo, mesmo não sendo um ator de trajetória ligada ao grupo, permitiu-se ter a experiência de montagem com o Oficina, fase importante e de crescimento para qualquer profissional (Bononi, 2011, p. 15).

\footnotetext{
${ }^{10}$ Em depoimento, a atriz Lizete Negreiros lembra que Lorival Pariz participou também da montagem infantil Dom Chicote Mula Manca e Seu Fiel Companheiro Zé Chupança, em 1972, tendo a iniciante Lucélia Santos como parceira de cena.

${ }^{11}$ Fonte: http://www.unicamp.br/unicamp/unicamp_hoje/ju/novembro2008/ju415_pag0607.php
} 
O ano era 1972, a ideia do milagre econômico brasileiro se propagava por todos os cantos, e muitos acreditavam nele. Em meio à fantasia e à dura realidade brasileira, um grupo de criadores teatrais e músicos idealizaram a montagem de $O$ homem de la mancha. Reuniram-se para o trabalho ninguém menos que Flávio Rangel, na direção, Chico Buarque, Ruy Guerra e Paulo Pontes na adaptação do roteiro, com o qual Dale Wassermann já havia trabalhado a partir da obra de Miguel de Cervantes.

O roteiro de Wassermann está ambientado na década de 1930, por isso os adaptadores brasileiros sugeriram um Brasil dessa década também, mas, precisamente, um manicômio em que um paciente chamado Cervantes chega na companhia de seu amigo Sancho. Logo se indispõe com os 'loucos' poderosos do local, que subtraem seus pertences. Para apaziguar o ambiente, um julgamento se instala, Cervantes, então, organiza sua defesa, convidando os loucos para fazerem uma peça de teatro. Mostram aos outros a história do fazendeiro Dom Alonso, que imagina ser um visionário conhecido como Dom Quixote.

No elenco principal, Paulo Autran, Bibi Ferreira, Dante Rui, Ariclê Perez, Antônio Mercado, Lorival Pariz e muitos outros, pois foram mais de quarenta pessoas envolvidas nessa superprodução do início da década de 1970. Depois, ainda viajaram com o espetáculo para o Rio de Janeiro, quando o personagem Sancho Pansa foi assumido pela interpretação de Grande Otelo.

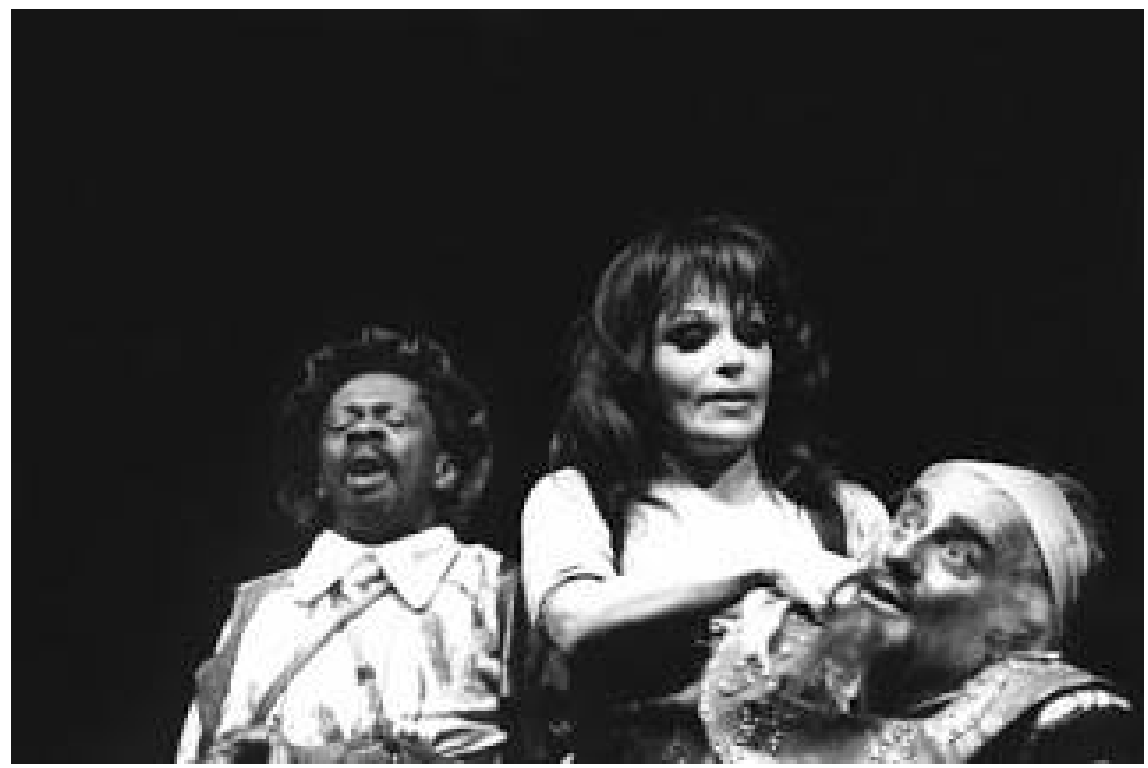

Grande Otelo, Bibi Ferreira e Paulo Autran parceiros de Pariz em O homem de la mancha ${ }^{12}$

A presença de Pariz nessa montagem demonstra a coerência com seus trabalhos anteriores, pois o roteiro de Wassermann traduz a potência de vontade do homem e a necessidade de apostar no mundo como idealidade, de insistir em ver a vida não apenas como ela é, mas também como ela deveria ser. Em síntese, a poesia como potência.

Mesmo sendo um espetáculo importado do modelo Broadway, a crítica ressaltou à época a capacidade do diretor Flávio Rangel de realizar adaptações para a

${ }^{12}$ Fonte: http://4.bp.blogspot.com/-DTOcZiVx2vM/UTUafiU8-CI/AAAAAAAowY/MJWIK9KgOKY/s1600/Bibi-HomedelaMancha.jpg 
realidade brasileira, além de elogiar o desempenho de um elenco selecionado e que desempenhou os personagens com ótimas interpretações. Lorival Pariz estava lá:

Ariclê Perez, Isaias Almada e Geisa Gama valorizam muito um trio vocal. Benedito Corsi faz um convincente interlúdio cômico. Antônio Petrin, Roberto Azevedo e Lorival Pariz assinalaram a sua presença. Estão bem preenchidos todos os pequenos papéis e apenas Dante Ruy precisaria imprimir maior brilho a Sancho, para não se apagar diante do Quixote. (Sábato, 2014, p. 265).

Com a montagem de $O$ homem de la mancha, Pariz vem reafirmar a sua interessante sabedoria e habilidade para fazer escolhas de repertório. Em plena década de 1970, falar de um poeta visionário, que enfrenta as adversidades com livros e poesias, demonstra a construção de uma trajetória pautada por ética e estética no ofício do ator.

O ano de 1973 apresentaria um novo desafio teatral a Lourival Pariz. A chegada à cidade da experiente atriz e produtora Madalena Nicol, depois de dezessete anos na Europa, criou a expectativa de que a atriz iria empreender algum projeto cênico interessante.

A cidade de São Paulo respirava as novidades das vanguardas artísticas, no campo teatral, havia muita empolgação com as montagens cênico-visuais de Bob Wilson, que viajavam o mundo e, inclusive, viria ao Brasil em 1974, e se apresentaria no Teatro Municipal de São Paulo com a peça/performance $A$ vida e o tempo de Josef Stálin.

Mas Madalena Nicol era uma 'clássica' mulher de teatro, advinda de um tempo que valorizava a importância da palavra, por isso, era vista, na década de 1970, como alguém que simbolizava os últimos suspiros do TBC (Teatro Brasileiro de Comédia), de um modelo de teatro que não mais era viável. Visando ao seu retorno, idealizou a criação de uma companhia estável para a montagem de O Carrasco do Sol, escrita por Peter Shaffer.

Uma produção que, sob a direção de Nicol, tinha no elenco, além de Lorival Pariz, figuras tais como: Antônio Pompêo, Marcos Caruso, Zanoni Ferrite e Ricardo Blat. Por meio da lembrança de Caruso, é possível vislumbrar um pouco das dificuldades que passaram:

Foi uma estreia desastrosa, por vários motivos. Primeiro, porque a montagem não era bem realizada e teve más críticas. Em segundo lugar, porque aprendi na carne que em terra de cego quem tem um olho é rei. No teatro universitário eu reinava, mas estava totalmente despreparado para o teatro profissional. E, em terceiro lugar, pela minha catástrofe pessoal. Em minha primeira entrada, eu teria que dizer: $O$ Atahualpa, venho em nome do imperador Carlos V de Espanha e Áustria... Entrei, muito nervoso, e disse: $O$ Carlos V, venho... Olhei para o Lourival e, atônito, percebi que não poderia dizer Venho em nome de Atahualpa, já que o tinha diante de mim, com uma imponente peruca de chefe inca (Rocha, 2007, p. 13).

A crítica recebeu a peça com algumas reservas. Foi bastante reconhecido o empenho de Madalena Nicol em retomar um teatro calcado na palavra, mas, por ser uma peça de um autor inglês, Sábato Magaldi entendeu, à época, que faltou uma melhor ambientação, principalmente por ser um tema que trata da conquista do Peru pelo invasor espanhol Francisco Pizarro. Um tema que, no teatro londrino, tinha seus atrativos, mas não tanto nos nossos palcos e no contexto brasileiro.

Mesmo criticando o conjunto, o esforço do elenco, incluindo Pariz, foi reconhecido. Nas palavras de Sábato Magaldi: 
Da estreia para esta semana o espetáculo ganhou ritmo e algumas interpretações cresceram. O confronto entre Pizarro e Atahualpa se faz agora em melhor nível, com Zanoni Ferrite e Lorival Pariz que dominam as personagens e souberam consolidar entre elas uma relação dramática. Luiz Fernando de Rezende, Ricardo Blat e Walter Martins são outros que se movimentam com domínio (Sábato, 2014, p. 298).

Observar o percurso de Pariz e analisar as escolhas que realizou permite constatar que foi um ator que procurava valorizar o seu ofício profissional, sempre buscando o contato com a palavra poética, portanto, exercitava um teatro de autoria. Verifica-se, também, um repertório que procurava interferir no contexto teatral e político do período. Trabalhava, assim, por uma crítica ao teatro das vanguardas artísticas e também por um teatro crítico às formas de dominação no Brasil e na América Latina, empreendidas pelos militares e seus incentivadores/invasores naquele contexto da década de 1970.

Em julho de 1973, estrearia em Curitiba uma das mais importantes produções brasileiras da década de 1970: Um grito para no ar, escrita por Gianfrancesco Guarnieri, mas, na ocasião, levada à cena pelo diretor Fernando Peixoto e produzida pela Othon Bastos produções artísticas. Uma montagem muito lembrada pela história da cena brasileira. Por um lado, por insistir na questão da resistência democrática, mas, por outro, por situar as dificuldades de fazer arte e teatro naquele contexto.

Mesmo tendo participado dessa histórica montagem, Lourival Pariz não esteve na estreia de: Um grito parado no ar, pois se sabe que ele foi incluído posteriormente no lugar de Ênio Carvalho, para interpretar o personagem Fernando. Na peça, este personagem é um diretor de teatro que tenta realizar seus ensaios, mas, dificilmente, consegue empreender um ritmo de trabalho, pois as intrigas cotidianas o impedem ou porque a crise econômica do grupo vai lhe retirando os equipamentos do teatro.

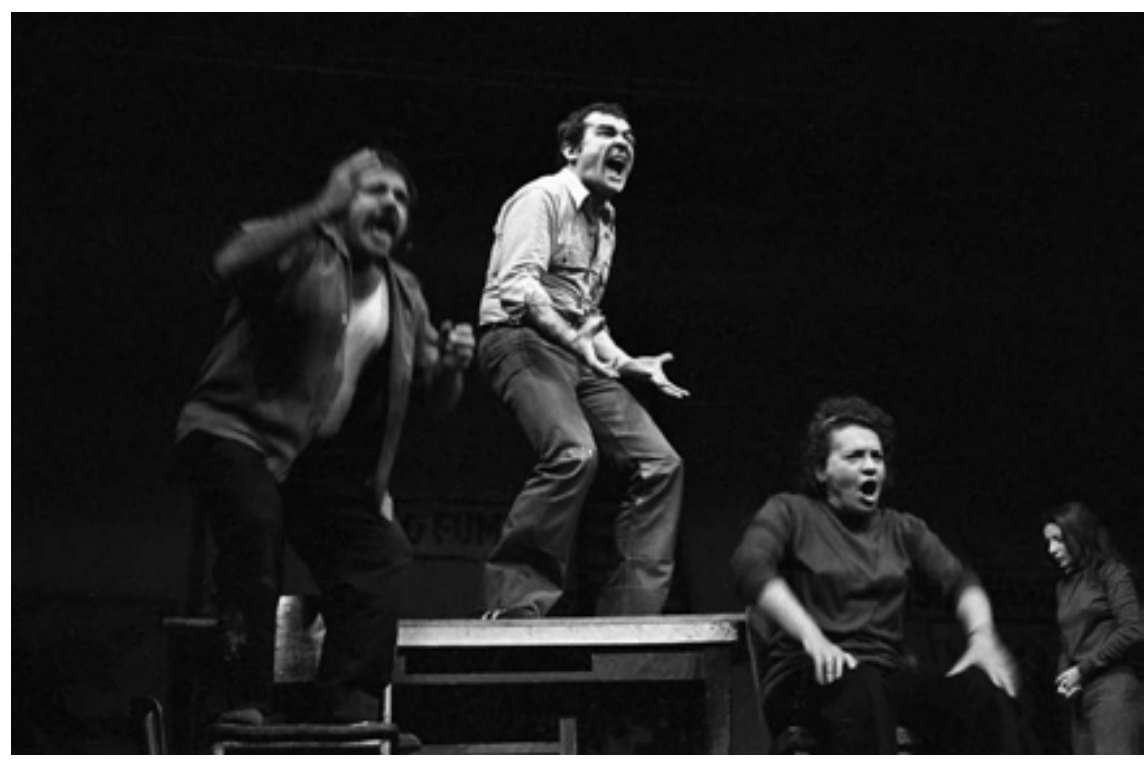

Cena do espetáculo Um Grito Parado No Ar: Osvaldo Campozana,

Othon Bastos, Liana Duval e Marta Overback, em (1973) $)^{13}$

Assim, a peça trata de um duplo estrangulamento econômico, numa primeira percepção, representa este país do milagre econômico, que não mede esforços para

${ }^{13}$ Fonte: http://www.iolandahuzak.com/ensaio/50 
a censura e para as torturas que estavam ocorrendo, mas também trata da situação de abandono que a arte e o teatro estavam passando. Assim, o personagem Fernando, interpretado por Pariz, é um chamado para a percepção da realidade. Fernando quer que os caprichos dos atores fiquem de lado e, consequentemente, priorizem refletir acerca do real que os envolve.

A participação de Lorival Pariz em Um grito... reforça uma trajetória que foi, anteriormente, sublinhada, qual seja, a escolha por um teatro que debate a realidade social e política. Assim, Pariz também esteve presente no que Guarnieri nomeou como sendo seu 'teatro de ocasião'.

E a ditadura civil-militar seguia em frente, mas não sem as resistências de quem acreditava na liberdade como princípio inalienável. Para se adequar e também desviar das imposições, muitos dramaturgos, diretores e atores optaram por caminhos metafóricos e, muitas vezes, alegóricos. Assim, não tratavam diretamente das agruras do contexto que estavam vivendo e, por meio de narrativas ambientadas em outros tempos e outras espacialidades, figuravam a dura realidade brasileira.

Dessa forma, muitas montagens retratavam distantes realidades brasileiras, com seus heróis da resistência, enquanto outras optavam por textos estrangeiros que evocassem as perseguições políticas e a ausência de liberdade. Assim foi com a montagem de Coriolano, de que Pariz participou em 1974, sob direção de Celso Nunes, levada à cena no Teatro Municipal de Santo André.

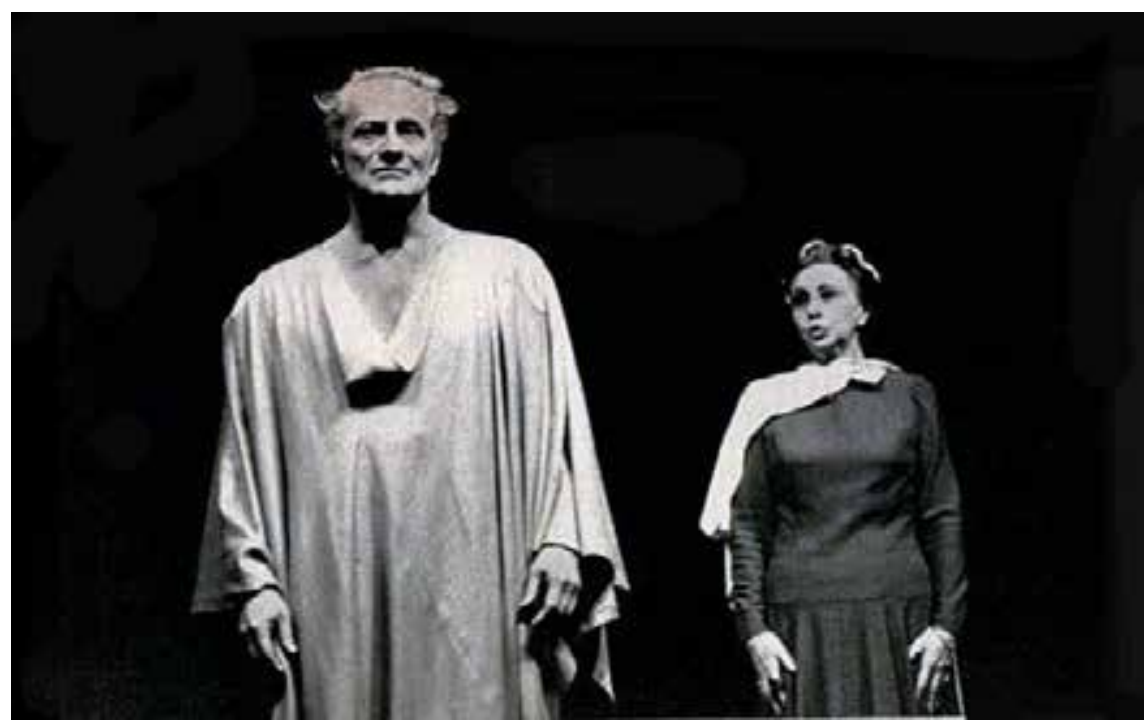

Paulo Autran e Henriette Morineau em Coriolano, $1974^{14}$

Este personagem shakespeariano é um dos que mais bem representam a ideia de que quem é contra o povo acaba tornando-se inimigo da pátria, portanto, um tirano. Estiveram a frente do elenco da montagem de Celso Nunes Paulo Autran e Henriette Morineau, mas contou também com um elenco de apoio bastante variado, como destaca Sábato Magaldi (2014, p. 344):

Era necessário que a primeira linha de atores, depois dos protagonistas, atuasse com a mesma convicção e eficácia. Jorge Chaia (Comínio), Luiz Serra (Menênio,

${ }^{14}$ Fonte: ttp://blogdoantonicodaigreja.blogspot.com.br/2016/08/paulo-autran-e-henriette-morineau.html 
Agripa), Hélio Ary (Sicínio, Veluto), Antônio Petrin (Junio, Bruto) e Lourival Pariz (Tulo, Aufídio), pela postura e pela autoridade, foram muito bem escolhidos e convencem no duelo de forças. Luiz Serra ainda precisa cuidar melhor da voz, para atingir o rendimento dos seus companheiros.

No geral a crítica foi bem receptiva à concepção de Coriolano, incluindo a concepção cenográfica de visualidade rústica de Marcos Flaksman. Evidente que as presenças de Autran e Morineau chamaram a atenção, mas o conjunto do elenco foi muito bem aceito e isso se evidenciou na presença do público durante a temporada.

Coriolano reforça o entendimento de que Lorival Pariz vinha realizando escolhas estéticas muito afinadas com os dilemas políticos de seu tempo. Mesmo diante da censura imposta, verifica-se que a sua atuação, nas brechas do sistema, permitiam a manutenção da crítica ao regime militar.

O ano de 1977 seria marcado pelo início do processo de abertura democrática, pressionado pelas mobilizações sociais e grandes greves do ABC paulista, os militares foram pressionados e tiveram que concordar com uma Lei de Anistia. Esses ventos de abertura circularam também pelo teatro. Nesse ano, entraria em cartaz uma nova experiência teatral de Lorival Pariz A morte do caixeiro viajante, protagonizada por Paulo Autran.

O realismo psicológico de Arthur Miller já havia sido encenado no Brasil, na década de 1950, mas voltava com toda força em 1977. O elenco, além de Autran, tinha Natália Timberg e Herson Capri, personificando os personagens da família Loman, pessoas desajustadas diante da realidade socioeconômica da década de 1930.

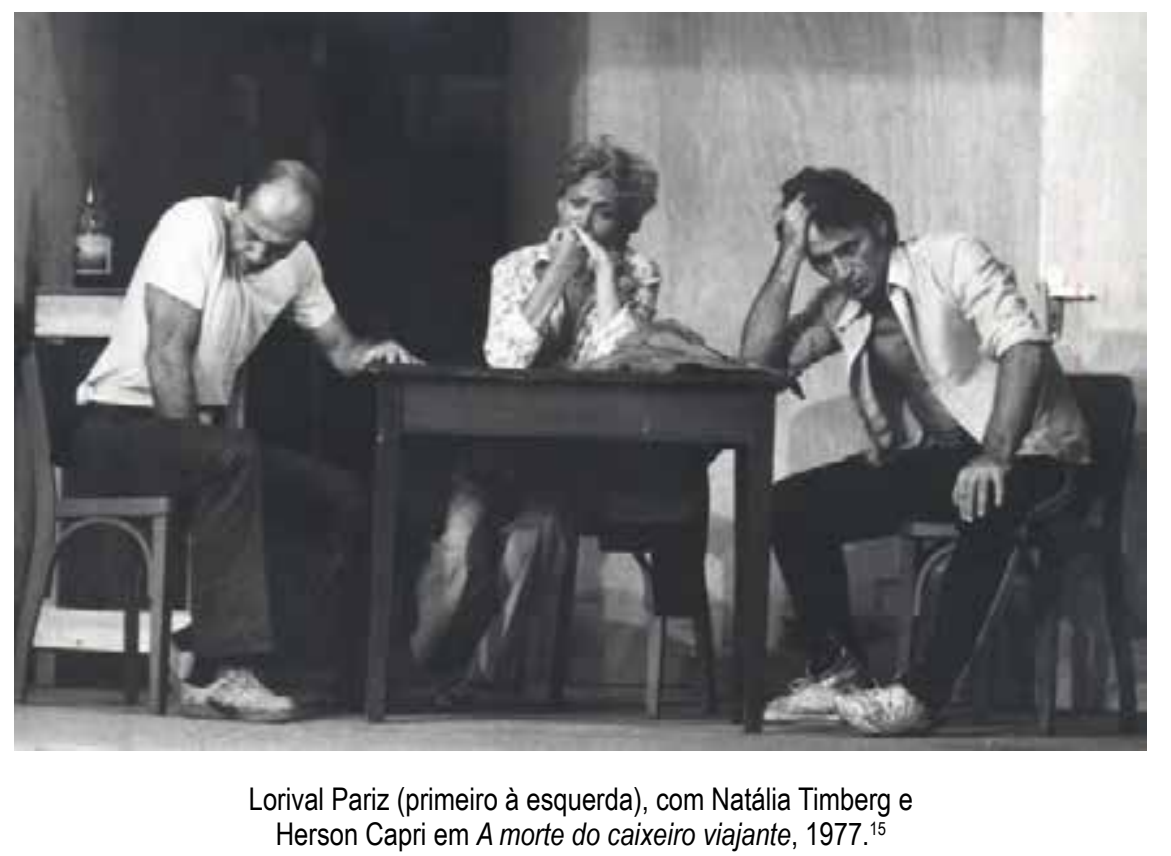

Pariz, nessa montagem, irá interpretar um dos filhos do caixeiro. A crítica do período não recebeu bem a montagem, principalmente o tom adotado pela direção de Flávio Rangel e a cenografia de Tulio Costa. Salva-se a interpretação de Paulo Autran, pois os demais são bastante criticados:

${ }^{15}$ Fonte: http://astrosemrevista.blogspot.com.br/2013/04/paulo-autran-no-teatro.html 
[...] Tem-se a impressão de que o diretor ensaiou o espetáculo em ritmo acelerado, por cenas isoladas, confiando na possibilidade de cada um resolver-se por si. Não se nota um elaborado trabalho sobre o elenco. Não se nota um elaborado trabalho sobre o elenco. Prova-o a atuação de Lorival Pariz, intérprete sabidamente competente e que, no papel do filho do caixeiro, não consegue apreender inteiramente o personagem. Quando se imagina que finalmente vai mergulhar na ação, alguma coisa desliga no seu desempenho. São constantes meios-voos [...]. (Del Rios, 2010, p. 100)

Nota-se um tom impositivo do crítico com relação ao trabalho da direção, cenografia e restante do elenco, preservando o protagonista Paulo Autran. Por outro lado, não se nota um aprofundamento da crítica na sua avaliação da interpretação dos atores, por exemplo, não aponta os estilos adotados, as teorias da atuação utilizadas durante a criação do espetáculo. Tratam o trabalho do ator como algo dado e sem processos, isto é, avaliam o ator pelo resultado em cena, tão somente.

Logo, no ano seguinte, 1978, Pariz se enveredaria por outra montagem da dramaturgia norte-americana, a escolha agora seria Edward Albee e seu importante texto The zoo story. As apresentações foram no Teatro Maria Della Costa, teve a direção de João Albano e contracenou à época com o ator Marco Nanini. Espetáculo este que lhes renderam o prêmio Governador do Estado de São Paulo.

Sente-se que Marco Nanini e Lorival Pariz examinaram com grande lucidez a peça, não se esquecendo dos vários aspectos pelos quais se deve encará-la. Nenhuma ótica discutível falseia a impostação do espetáculo, que absorve a trajetória histórica já cumprida pela obra, inclusive na sua influência sobre a dramaturgia brasileira [...]. (Sábato, 2014, p. 535)

O prêmio recebido foi resultado de muito trabalho e nota-se a aceitação da crítica ao espetáculo, que reforça o desempenho dos dois atores, enaltece a direção, mas também não aprofunda muito nas características e escolhas que cada ator fez para seu personagem. Mas, com certeza, mesmo sendo um texto que projeta mais o personagem Jerry, a atuação de Pariz, com seu discreto Peter, chamou atenção naqueles fins de década de 1970.

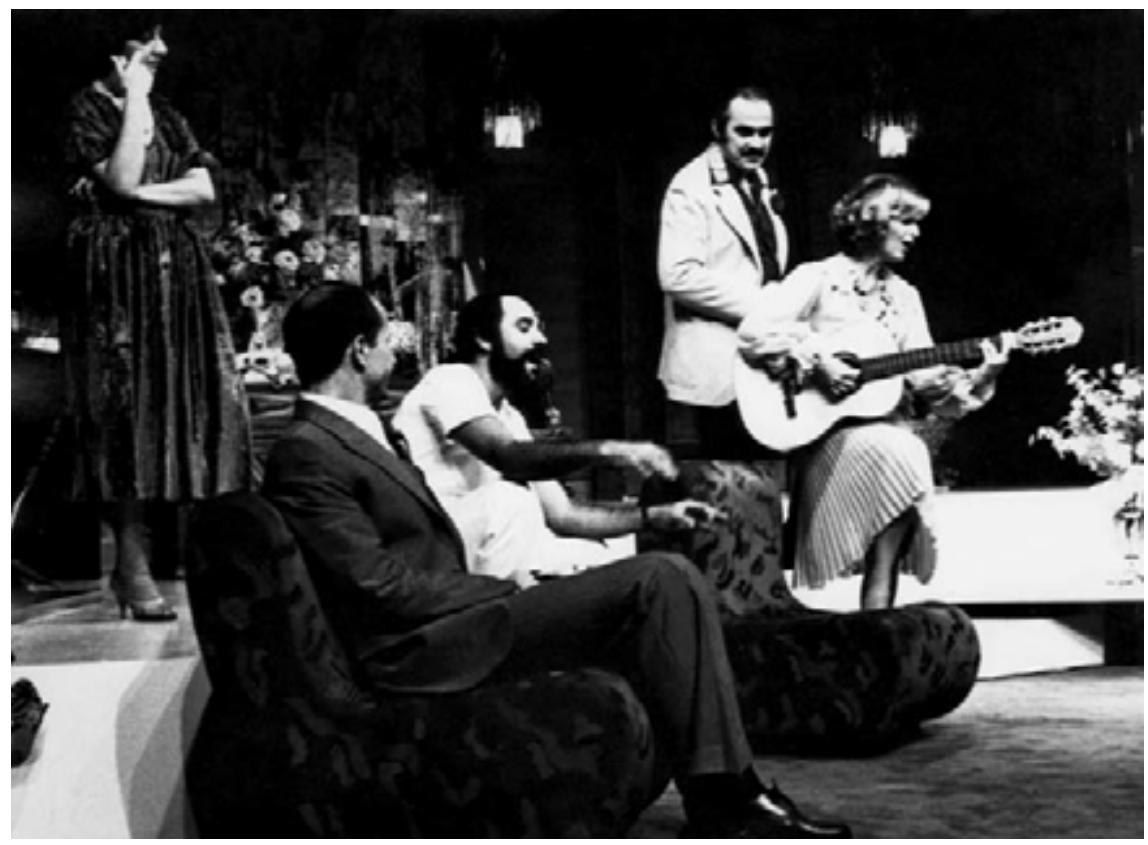

Pariz (primeiro sentado) e o elenco de Bodas de Papel, em 1978 16

\footnotetext{
${ }^{16}$ Fonte: Góes, 2008, p. 103.
} 
Olhar a trajetória de Pariz no teatro é notar que uma montagem leva à outra. Foi assim que apareceu a proposta de fazer Bodas de Papel, de Maria Adelaide Amaral, no Rio de Janeiro, em 1978. Uma peça que retrata crise de altos executivos com um estilo de vida que quase sempre leva à desumanização (Amaral, 2005, p. 78).

Os depoimentos da autora Maria Adelaide Amaral, como da atriz Regina Braga, lembram o ótimo ambiente do elenco e a aceitação do espetáculo pelo público. Envolver-se num trabalho de uma dramaturga brasileira que lançava seus primeiros textos demonstra a disponibilidade de Pariz para o novo, seja estrangeiro, seja nacional. Percebe-se também a escolha por textos que possuem um tom crítico com relação à realidade brasileira, como era o caso Bodas de Papel de Maria Adelaide.

A relação de Pariz com a televisão ${ }^{17}$ merece um capítulo à parte, pois, desde os anos de 1970, nota-se uma aproximação do ator com esse suporte, mas nota-se também certas desconfianças, algo muito próprio de sua geração, que viam no teatro um ofício, uma missão a ser exercida sem meias concessões. Assim, merece lembrança a participação de seu personagem Dr. Eugênnio, em Nino, o italianinho, de 1969. Merece ser mencionado também o teleteatro de que participou em 1979, quando o programa TV Aplauso, da Rede Globo, levou ao ar a filmagem de $O$ santo inquérito, de Dias Gomes, sob a direção de Antônio Mercado. Mesmo ano em que fez também Queridos, fantásticos sábados, dirigido por Domingos Oliveira na mesma emissora. E, como mencionado acima, sua destacada participação em Sassaricando, no fim da década de 1980, como o personagem Bóris.

Associado ao ofício do ator, Lorival Pariz procurou, em sua trajetória, desenvolver experiências de ensino, como foi o caso de sua participação na montagem de Senhorita Julia, na Escola de Arte Dramática, em 1989, e, posteriormente, já como professor do Curso de Artes Cênicas na Universidade Federal de Uberlândia (UFU), onde, além de ministrar aulas, dirigiu o espetáculo Ensaio de orquestra, e, em 1994, participou da montagem de El dia em que me quieras. Cursos e espetáculos que vieram a reforçar seu interesse pelos fundamentos do trabalho do ator.

\section{III}

Paralela a essa intensa atuação teatral, Pariz foi também um homem de profunda dedicação ao cinema brasileiro. Na história do teatro e da cinematografia, não se tem muitas referências do que ele fez até 1969, quando realizou, talvez, o mais importante projeto de sua vida: interpretar o personagem Coirana, em $O$ dragão da maldade contra santo guerreiro ${ }^{18}$, de Glauber Rocha. Filme que projetou sua imagem nacional e internacionalmente.

Para entender esse filme, faz-se necessário retomar um pouco do primeiro, qual seja, Deus e o Diabo na Terra do Sol, do qual Pariz não participa, mas no qual Glauber apresenta ao mundo seu personagem Antônio das Mortes, o matador de cangaceiro. Deus e o Diabo é uma narrativa que antecede ao golpe, momento em que as expectativas de transformação ainda estão apresentadas sobre a mesa, há um horizonte de esperanças que podem se realizar na política do presente histórico ou na busca de utopias.

\footnotetext{
${ }^{17}$ Para a TV brasileira, ainda em seus primórdios, Lorival Pariz trabalhou também nas telenovelas/séries: 'A Fábrica' (1971) e 'Eu e a Moto' (1972).

${ }^{18}$ Para participar de festivais internacionais, Glauber optou por intitular o filme de Antônio das Mortes, até hoje se encontra cartazes com esse título.
} 


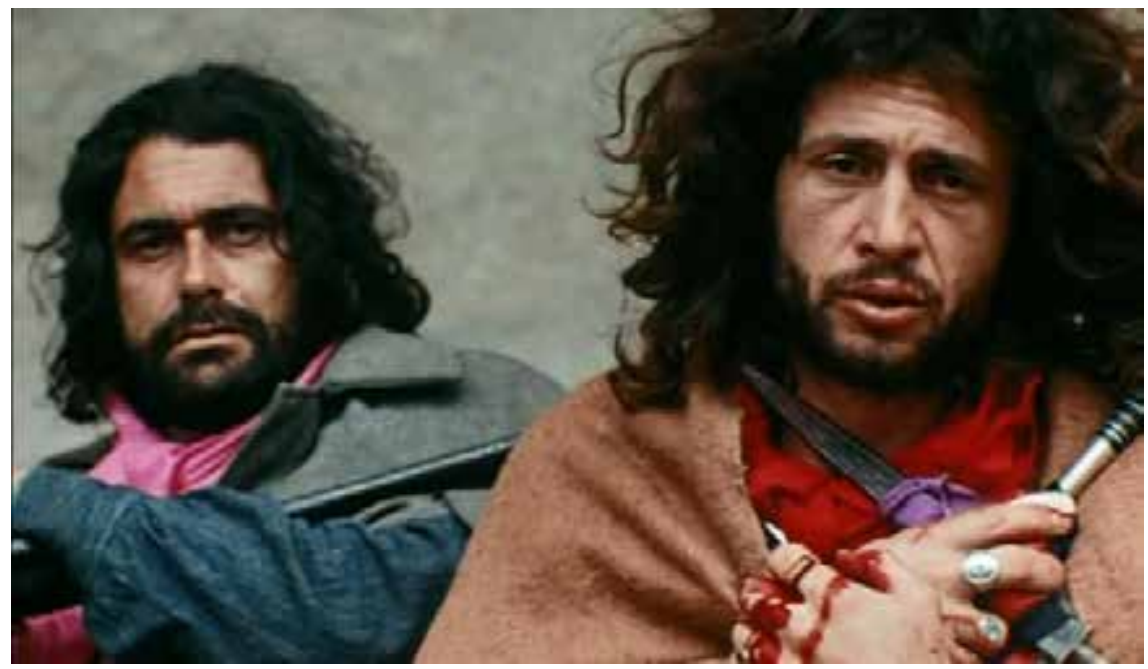

Lorival Pariz e Maurício do Vale em 0 dragão da maldade contra o santo guerreiro, de Glauber Rocha ${ }^{19}$

Em poucas palavras, o filme narra a história do vaqueiro Manoel, que, fugindo da seca, da fome e do desencanto procura refúgio material e espiritual nas experiências que o imaginário nordestino do momento lhe apresenta: o messianismo religioso e o cangaço. Para combater essas duas alternativas, o histórico coronelismo da região aciona outro de tipo de força, também histórica na região, o matador, o justiceiro de aluguel, no filme incorporado por Antônio das Mortes e interpretado pelo ator Maurício do Valle.

Glauber nos mostra, então, o personagem Manoel envolvido nas promessas de um Beato, que the envolve numa profunda experiência messiânica, mas que também lhe retira a percepção das coisas e de suas necessidades materiais mais elementares. Tendo escapado do justiçamento de Antônio das Mortes, Manoel e a esposa Rosa seguem sua saga. Pelo caminho encontram o cangaceiro Corisco (Othon Bastos) e seu bando, que Ihe apresenta a possibilidade da transformação e superação da pobreza pelo uso da força e da violência, mas, mais uma vez, é interrompida pela chegada de Antônio das Mortes.

Corisco, apenas com a memória de Lampião, enfrenta, mas não resiste ao seu oponente e cai derrotado. Manoel e Rosa correm em direção ao mar. Ao fim, ao som de "o sertão vai virar mar e o mar virar sertão", na voz de Sérgio Ricardo, a mística nordestina de busca da água primordial se realiza/finaliza como narrativa.

Num necessário salto na obra de Glauber, deixemos Deus e o Diabo e avancemos para o personagem de Lorival Pariz, em $O$ dragão da maldade contra o santo guerreiro, no qual representa o cangaceiro Coirana, nome e palavra que indicam na língua portuguesa uma variedade de cestos. Não temos ainda informações de como Pariz foi selecionado para o elenco do filme de Glauber, mas tudo indica que fazia parte, em Salvador, de pessoas próximas aos cinemanovistas, por exemplo, de Othon Bastos, que, posteriormente, faria outros filmes com Glauber, bem como incorporaria Pariz à sua produtora de peças teatrais.

O filme O Santo Guerreiro se apresenta, inicialmente, como possível continuidade de Deus e o Diabo, uma vez que se verifica a reiteração de personagens que haviam participado do filme de 1964. Por exemplo, Antônio das Mortes, que regressa

${ }^{19}$ Fonte: $h$ htp://www.rtp.pt/cinemax//?t=ANTONIO-DAS-MORTES-1969.rtp\&article=11338\&visual=2\&l ayout=\&tm= 
ao interior do Nordeste após saber da presença do último dos cangaceiros, justamente Coirana, interpretado por Pariz.

O personagem Coirana, nas primeiras cenas do filme, chega à praça central da cidade dançando com o povo e, de arma em punho, mistura-se à gente da cidade numa amálgama de procissão e transe religioso. Na sequência, no centro da mesma praça, anda em círculos com Antônio das Mortes. Tudo indica que teremos um combate, tal como no filme anterior, mas não, Glauber não cede aos roteiros de faroestes norte-americanos ${ }^{20}$, pois o que se vê é uma declamação de trechos de cordel dando o tom, além de uma luta de facões que remete muito mais a elementos da cultura popular nordestina do que a um desafio ou duelo.

Essas referências ao cordel, indicadas por Glauber, aparecem na análise de Sylvia Nemer:

\begin{abstract}
Dirigida ao público mais do ao próprio adversário, a apresentação é o momento da performance em que os poetas falam de suas proezas ao mesmo tempo que insultam o oponente chamando-o de fraco, covarde, corno, etc. Dependendo da capacidade de improviso dos poetas, os insultos se estendem, o público se envolve, dá risadas, apoia um dos cantadores, enfim, entra no jogo. Na verdade, tudo se passa mesmo nesse nível, do jogo, do duelo verbal, da violência simulada [...]. (Nemer, 2008, p. 270)
\end{abstract}

Do confronto em diante, Coirana de Pariz torna-se um personagem que serve para demonstrar a crise de consciência de Antônio das Mortes, que não mata Coirana, tal como havia matado sem piedade Corisco no filme anterior. Além de não ser morto por Antônio, Coirana segue perambulando com sua dor pelas redondezas do vilarejo.

A presença de Lorival Pariz, nesse filme de Glauber, com certeza irá marcar profundamente a trajetória seguinte desse ator, da mesma forma que marcou a vida de outros atores, tais como Othon Bastos e Maurício do Valle. Marcas de um tempo, ícones de uma geração.

Trabalhar com Glauber foi, sem dúvida, um divisor de águas na carreira de Pariz, com certeza lhe abriu portas. Nos próximos anos, voltaria às telas com outros filmes, mas nenhum tão impactante quanto a experiência com o cinema novo.

Pariz também tinha, nesse fim de década de 1960, uma capacidade de transitar por diferentes projetos cinematográficos. Nota-se que, depois da experiência glauberiana, ele irá envolver-se num segmento de cinema que se diferenciava bastante daquele experienciado com os cinemanovistas, qual seja: o cinema marginal. No entanto, essa ligação é contestada pelo diretor João Batista de Andrade, numa recente entrevista para a Folha de S. Paulo:

No filme, um jornalista (Pereio) é acossado e oprimido por três estranhos personagens. Clima de perseguição e de fuga. O jornalista acaba abandonando sua profissão e se escondendo numa casa de periferia, onde vive como artesão até ser descoberto pelos três opressores. Eles destroem os objetos de seu trabalho e surram tanto o jornalista quanto sua mulher (Fromm). Entre esses personagens, manipulado pelos três demônios, um mendigo apocalíptico, justamente o Gamal do título, é usado para perseguir o jornalista e sua mulher.

\footnotetext{
${ }^{20}$ Esta associação aos faroestes é criticada por Ismail Xaviel em "Alegorias do Subdesenvolvimento", disponivel em: https://books.google.com.br/books?id=0c0YAAAAQBAJ\&pg=PT298\&lpg=PT298\&dq=personagem+coirana\&source=bl\&ots=204Z_OudL_\&sig=FAXTciZ4LbCSC8oHqrwMmmS1LbQ\&hl=pt=-BR\&sa=X\&vedOahUKEwj_iOSm_PbNAhVCIJAKHYCgAYQQ6AEIQTAH\#v=onepage\&q=personagem\%20coirana\&f=false
} 
Um clima bem de época, em seguida ao AI-5, num filme sem qualquer controle narrativo, caótico, carregado de desespero.

O título original era só Gamal, mas vendi o filme para um produtor da Boca do Lixo para pagar a dívida do financiamento do banco. Para atrair o público das pornochanchadas, adicionamos um complemento mais apelativo. Assim surgiu Gamal, o delírio do sexo (Andrade, 2016, p.1).

Desse modo, passada a fase Glauber Rocha e de envolvimento no projeto cinemanovista, o ator Lorival Pariz volta-se para outras possibilidades dadas pela cinematografia nacional. Foi pelas mãos de João Batista de Andrade que irá participar de Gamal, o delírio do sexo. Num breve resumo de enredo, pode-se narrar que Gamal é a história de um jornalista que percebe a sua impotência política e entra em desespero. Numa narrativa bastante fragmentada, que impede analogias fáceis com a realidade brasileira, mas estão ali os dilemas do país no pós Al-5. O filme retrata a angústia e o medo que imperava naquele momento de repressão e censura.

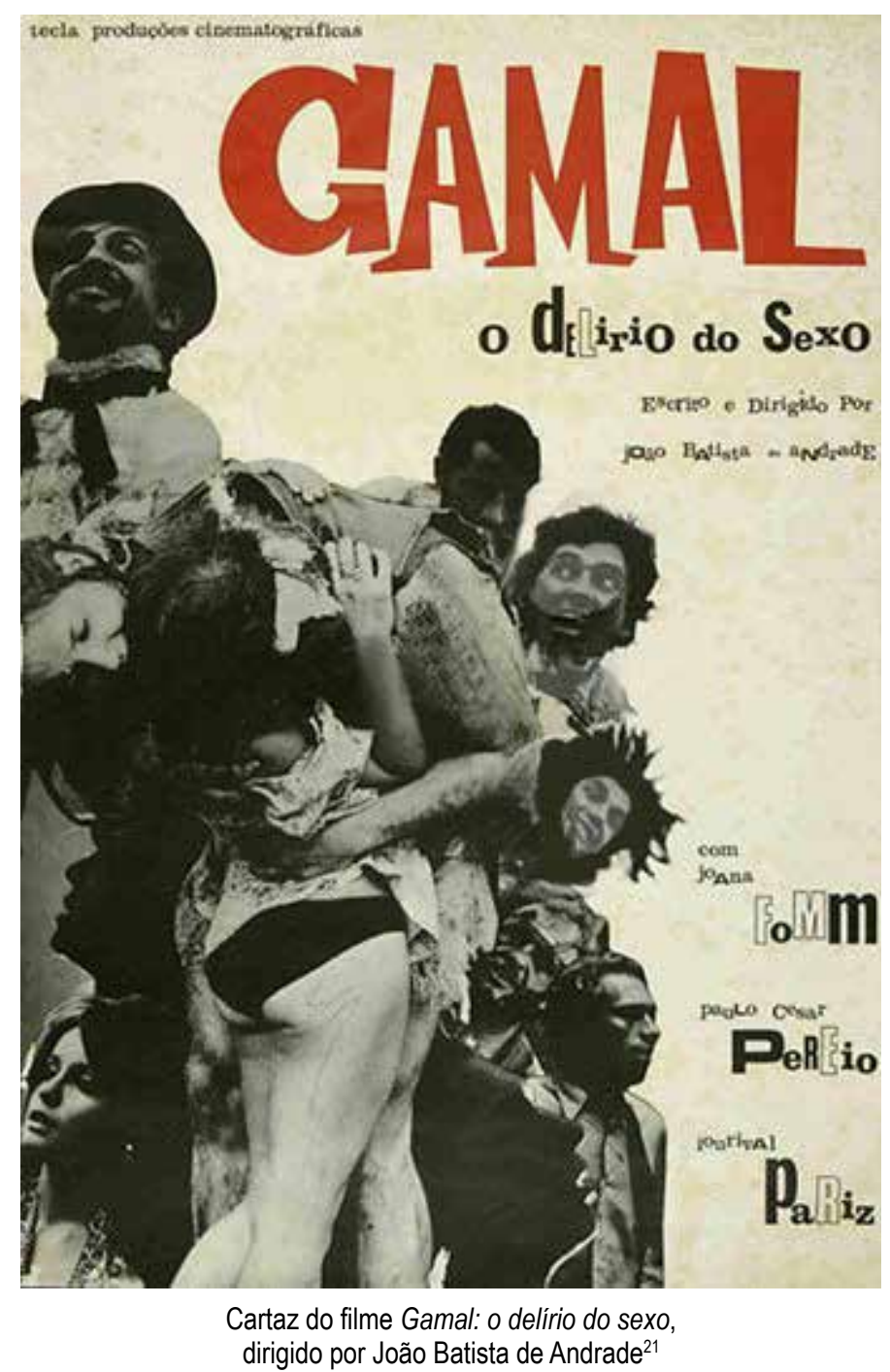

Verifica-se, portanto, a capacidade e versatilidade do ator Lorival Pariz para envolver-se em diferentes projetos cinematográficos, pois do Coirana de Glauber partiu para outra 
proposta. Da referência nordestina, que se pretendia leitura da realidade nacional, partiu para as referências do cinema 'udigrudi', mesmo que negado pelo diretor, mas mais conectado com os problemas das grandes cidades, especificamente, São Paulo, e também com as perseguições impostas pela ditadura civil-militar.

Em Gamal, há que se destacar as interpretações de Joana Fromm e do teatrólogo Fernando Peixoto. Joana Fromm se tornaria conhecida, posteriormente, pelas telenovelas, e, o segundo, pela participação no teatro oficina, na direção de Um grito parado no ar' e pelas inúmeras publicações sobre Brecht no Brasil, sendo, inclusive um de seus principais tradutores para o português brasileiro.

Na sequência, em 1971, Lorival Pariz enveredou-se por uma experiência com outro tipo de cinema, quando aceitou fazer parte do elenco que fez o filme Paixão na praia, dirigido por Alfredo Sternheim. Em breves palavras, a sinopse do filme é a história de uma esposa frustrada de um industrial burguês, que tem sua mansão invadida por dois marginais. $O$ que seria um ato de violência vai se configurando num misto de culpa, revolta e amor, a partir do triângulo formado por eles. Pariz, no caso, interpreta o empresário, que aparece no início da película, viaja e só retorna ao final.

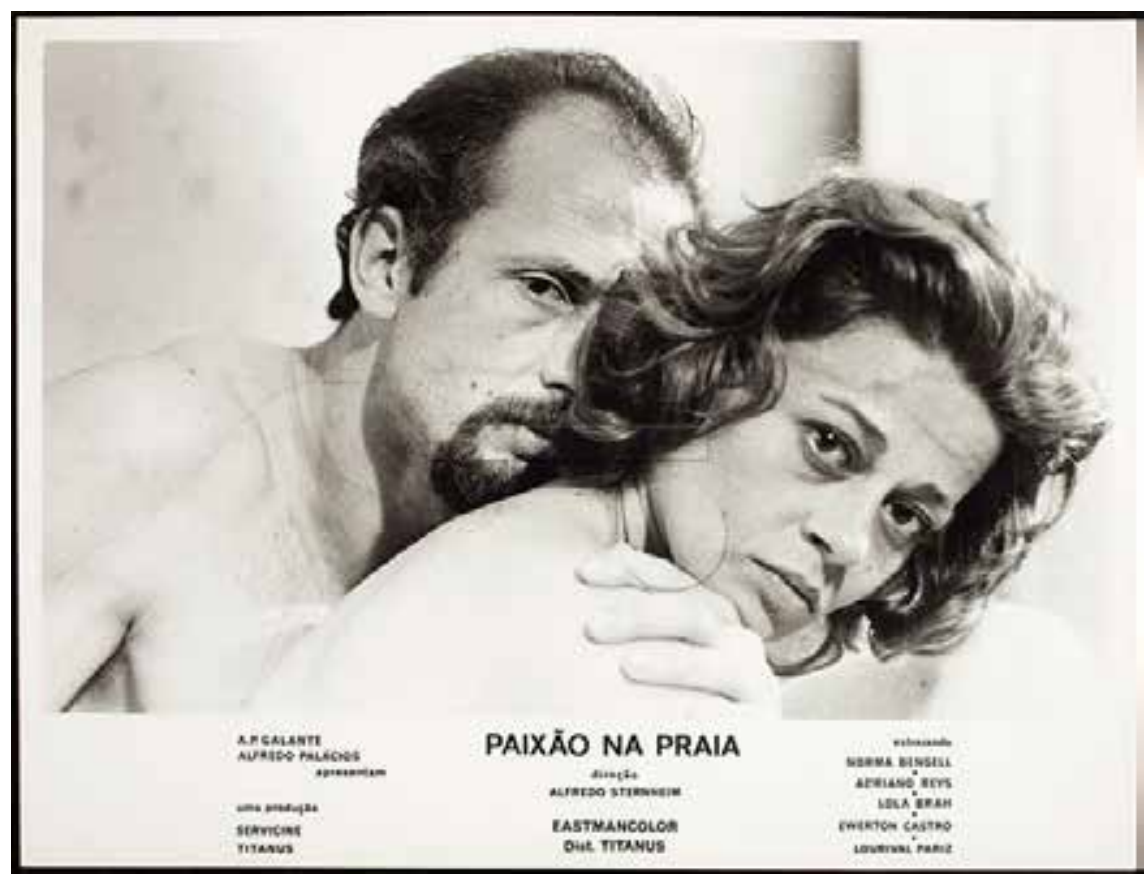

Lorival Pariz e Norma Bengell em Paixão na Praia, filme de 1971, dirigido por Alfredo Sternheim²2

Além de Pariz, destacam-se as presenças de Norma Bengell, Adriano Reys e Ewerton de Castro, este último em um de seus primeiros filmes. $O$ filme também não deixa de ter certa aproximação com o clima de erotismo despertado no período por produções conhecidas como as pornochanchadas. Principalmente, nas cenas entre Norma Bengell e Adriano Reys, carregadas de sedução, mesmo sendo entre sequestrador e cativa. Isso, claro, depois do diretor indicar muitos sinais de que a personagem de Bengell era uma mulher insatisfeita no casamento.

A interpretação de Pariz já denota uma construção diferenciada, com elementos

${ }^{22}$ Fonte: http://www.bcc.org.br/fotos/galeria?page=3166 
teatrais presentes na sua fala e gestos pausados, mesmo que o filme apresente sinais de que a sonorização tenha sido feita posteriormente, o que era comum no cinema brasileiro do período.

Na sequência, em princípios da década de 1970, Lorival Pariz enveredaria por outra experiência cinematográfica. Dessa vez aceitou fazer o filme $O$ homem do corpo fechado, dirigido por Shubert Magalhães. Em breves palavras, o enredo do filme acontece em torno da figura de João de Deus, interpretado por Roberto Bonfim. João é considerado um vaqueiro com o corpo fechado e que, após ser contratado por um latifundiário, apaixona-se pela filha de seu patrão e foge com a mulher. Após a descoberta da fuga, o coronel rapidamente manda capturar o homem e sua filha. É nesse instante que surge o personagem interpretado por Pariz, que será Turíbio, o enviado pelo grande latifúndio para recapturar a moça e devolvê-la a seu pai.

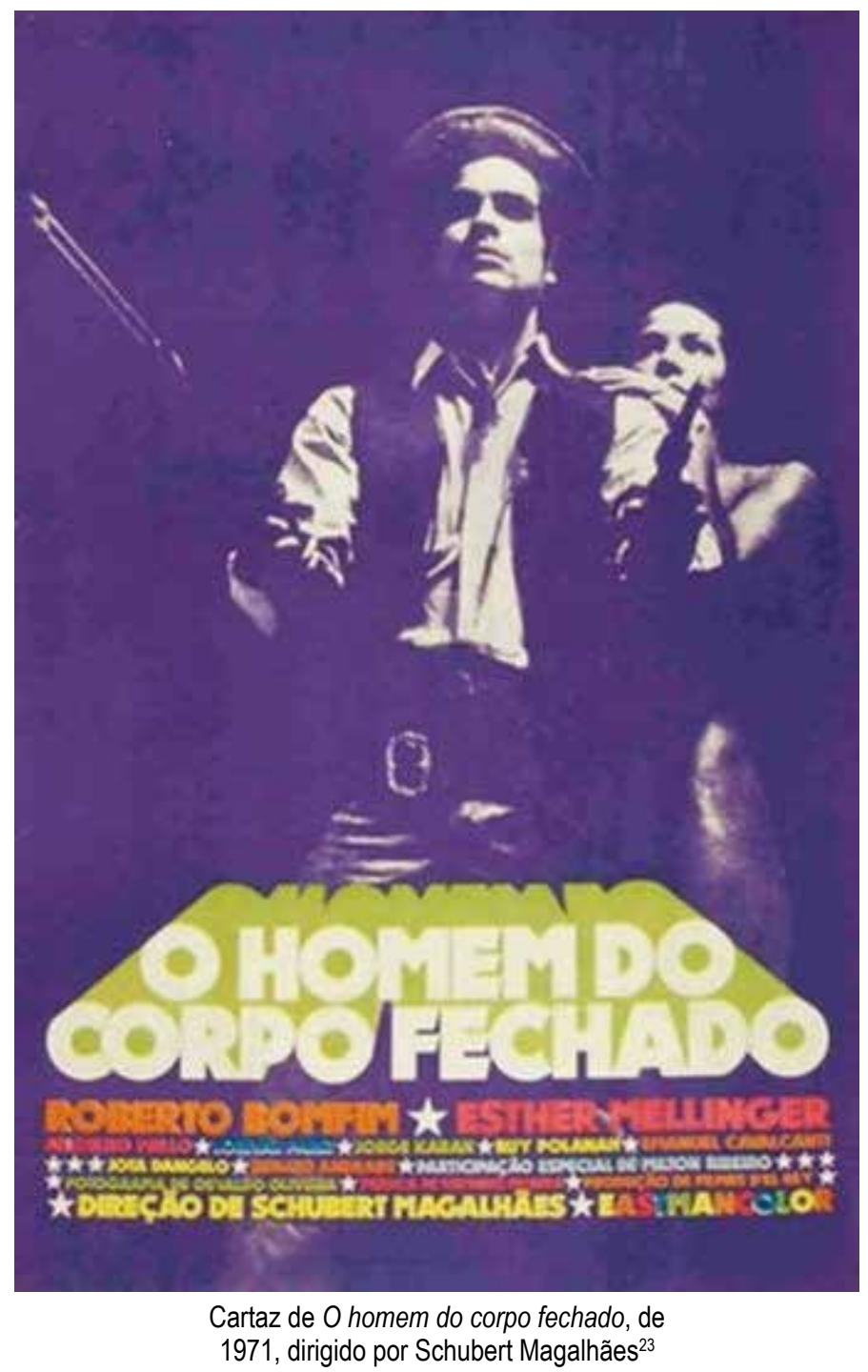

Em seu percurso, Turíbio viaja pelas regiões de Minas Gerais, locação do filme e, num determinado momento, encontra um violeiro próximo a uma ponte, dedilhando seu instrumento. Naquele princípio da década de 1970, esse homem da viola ainda era um desconhecido, somente anos depois, o Brasil conheceria a fama de um de seus ins-

${ }^{23}$ Fonte: http://bangbangitaliana.blogspot.com.br/2015/07/o-homem-do-corpo-fechado-especial.html 
trumentistas mais habilidosos e renomados, Renato Andrade. Uma pequena 'ponta' no filme, mas, para quem revê hoje em dia é, sem dúvida, uma presença bastante singular.

Este filme de Shubert Magalhães ficou, por muito tempo, esquecido, mas somente anos depois veio a ser restaurado e, hoje, é considerado uma das películas mais interessantes da chamada cinematografia mineira. Nota-se que o diretor tentou ambientar em Minas e também dar uma coloração do universo roseano à sua história. Além disso, o filme pode ser visto como sendo de uma vertente de filmes que, desde a década anterior, tentaram dialogar com a questão do faroeste norte-americano.

Outro ponto instigante de ser analisado é o fato de Pariz, nesse filme, tentar recuperar um pouco da imagem do cangaceiro Coirana. Talvez essa escolha tenha sido do diretor, mas nota-se certa proximidade na construção entre Coirana e Turíbio, ambos matadores a serviço das elites rurais brasileiras.

Muito interessante notar a presença cênica de Pariz neste filme, que traz uma imponência corporal, uma limpeza gestual, que não se vê presente em outros atores. Os momentos singulares de sua participação no filme são sua conversa, regada a uma dose de cachaça com o Coronel e, outra, ao fim, a cena da batalha com armas de fogo entre Turíbio e João de Deus. Após deporem as armas batalham com seus sabres/facões, lembrando a clássica luta entre Coirana e Antônio das Mortes, em O dragão da maldade contra o santo guerreiro, realizado três anos antes, em 1969. Nota-se, assim, uma inversão de personagens e suas funções, pois, com Glauber Pariz, interpretara o Cangaceiro ou, o último deles, no entanto, em $O$ homem do corpo fechado, ele encarna justamente a figura do matador. Uma demonstração da força dos filmes de Glauber, seus personagens e suas narrativas em outras obras da cinematografia nacional. Mas também da força da interpretação de Lorival Pariz.

Novamente há um interessante debate a respeito da relação entre filmes de Glauber Rocha e seus possíveis diálogos com o faroeste americano. Referência esta que o filme $O$ homem do corpo fechado faz questão de reforçar, no entanto, há um artigo de Ismail Xavier que refuta essa referência na filmografia de Glauber e, para isso faz uma interessante análise de O Cangaceiro, de Lima Barreto, comparando com Deus e o Diabo. Nota-se, portanto, a participação do ator Lorival Pariz nesses dois projetos, esteticamente antagônicos em suas referências. Sinal de que sempre esteve aberto a múltiplos caminhos a respeito de escolhas de narrativas e estilos de representação.

A presença do ator Lorival Pariz em filmes que tematizaram questões mais nacionais voltaria a acontecer em 1986, logo após o início da redemocratização brasileira, quando participou do filme 'O País dos Tenentes', com argumento, roteiro e direção de João Batista de Andrade, com quem voltaria a trabalhar depois de Gamal. Pariz interpreta um militar de patente, filho do personagem vivido por Paulo Autran. Em breves palavras, o filme narra a vida de um general da reserva homenageado por uma grande multinacional, mas que se vê diante de crises de consciência ao rememorar sua participação na história brasileira, recheada de conspirações, inclusive entre os membros da casta militar da qual faz parte. 


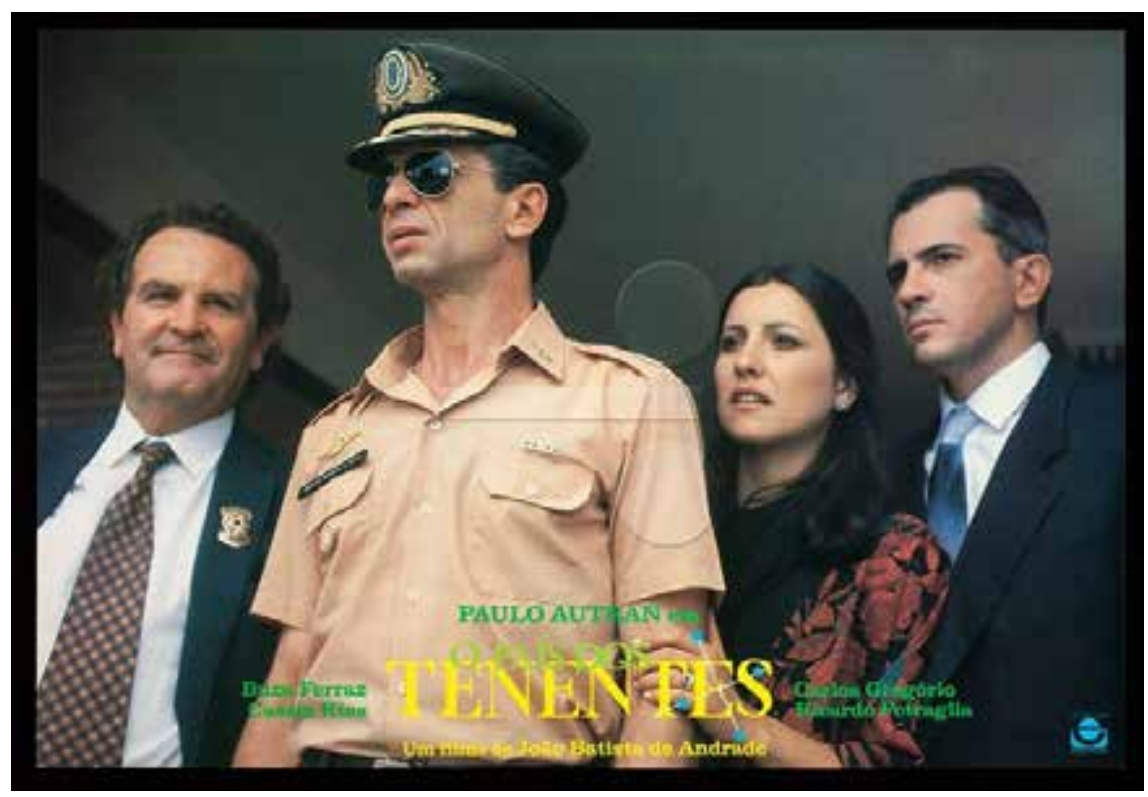

Lorival Pariz, à frente, no filme O País dos Tenentes, dirigido por João Batista de Andrade ${ }^{24}$

O filme de João Batista de Andrade foi bastante reconhecido quando lançado e inclusive premiado em Brasília, pois atualizava o tema da presença militar na história brasileira, justo ele que havia sido perseguido e censurado pela ditadura no pós 1964 . Já havia alcançado algum reconhecimento com $O$ Homem que virou suco, mas foi mesmo com $O$ País dos Tenentes, que demonstra uma envergadura consistente para transitar cinematograficamente por temas delicados e nacionais. Pariz, que já enfrentara questões nacionais junto com Glauber, volta às narrativas metafóricas por intermédio da narrativa proposta por João Batista de Andrade.

\section{IV}

Ao longo dessa trajetória teatral e cinematográfica de Lorival Pariz, existem outras inúmeras experiências desse ator com a televisão que ainda serão e merecem ser pesquisadas. Outros artigos ainda podem ser escritos acerca de sua experiência docente, como professor de interpretação teatral e expressão corporal ${ }^{25}$.

O deslocamento espacial e geográfico desse atuador das artes cênicas também merece alguns futuros capítulos, pois seu trânsito entre Bahia, São Paulo, Los Angeles e Minas Gerais deixou contribuições cênicas e fílmicas que devem ter dialogado com as pessoas e poéticas desses lugares.

Assim, no presente momento deste texto, o que se percebe é um percurso instigante de Lorival Pariz com o teatro e o cinema brasileiros. Percebe-se, em sua trajetória, que ele nos apresenta uma escolha de personagens muito bem pensada, sempre calcadas em projetos de alcance mais coletivos, que reunia elencos maiores.

Nas escolhas teatrais de Pariz, verifica-se uma preocupação com um teatro que

\footnotetext{
${ }^{24}$ Fonte: http://www.bcc.org.br/fotos/galeria/025525

${ }^{25}$ Sabe-se que Pariz viveu por alguns anos em Los Angeles, onde foi um introdutor das práticas da capoeira. https://www.facebook.com/Lorival-Pariz-Capoeira-Professor-First-Generation-Los-Angeles-478506518930320/
} 
valorizasse a arte da palavra, da narrativa e da construção de personagens complexos. Em todos os projetos que se envolveu, há um elemento em comum que foi a crítica à realidade que vivia, quase sempre esteve explícito o enfrentamento com ditadura civil-militar que ocorria no Brasil. Personagens que duvidavam dos poderes instituídos e que confrontavam um mínimo de ausência de liberdade de expressão.

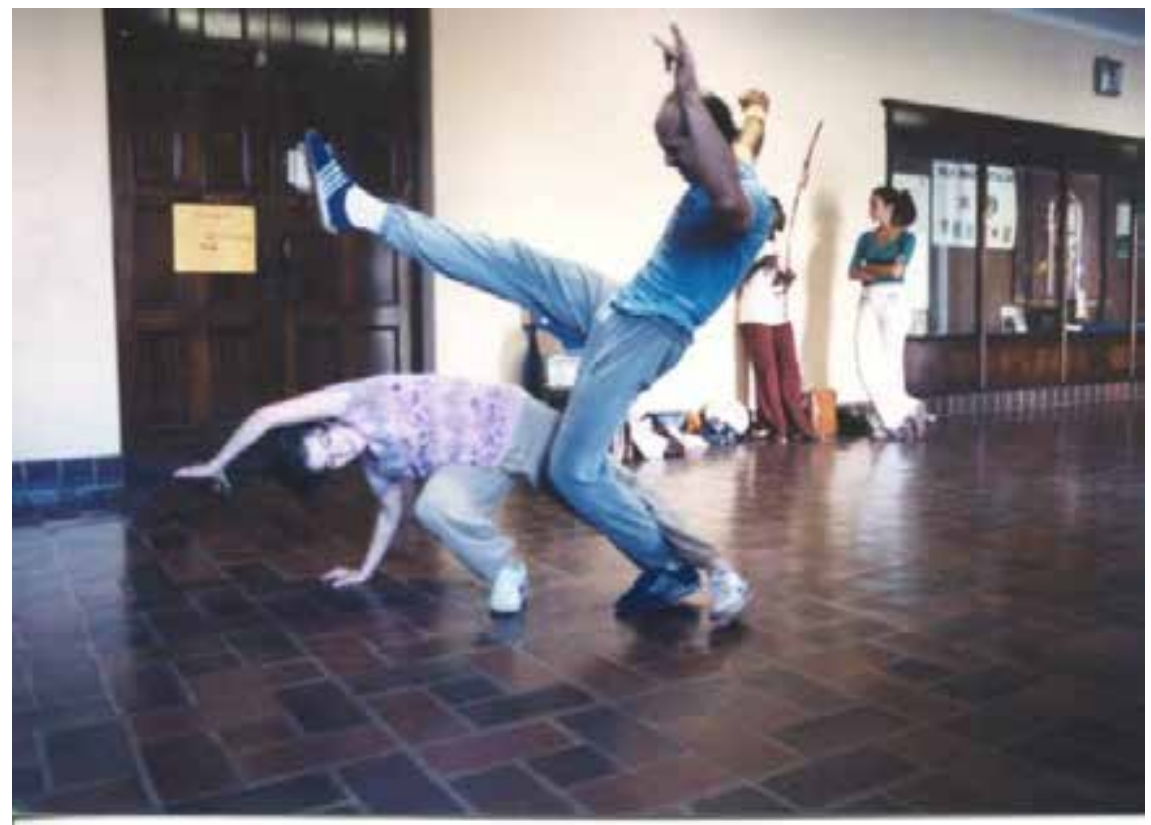

Pariz e a capoeira, em Los Angeles ${ }^{26}$

No cinema, também se envolveu em projeto de grande alcance como, por exemplo, com o cinema novo. Mas também opções do momento, como o caso de Paixão na praia, película que dialogava com as pornochanchadas da década de 1970, na qual fez parceria com uma das atrizes símbolo do período, Norma Bengel. Inegável que esse segundo filme também foi uma aposta em maior bilheteria, seja pelo elenco seja pelo formato atrativo naqueles tempos.

Há, ainda, revisitações temáticas, como O homem do corpo fechado, no qual reencontra a figura do personagem 'matador'. Tudo isso se soma a produções de caráter e debate mais nacional, tal como Gamal e Tenentes, ambos tendo problemas com a censura do período. Filmes esses, também muito ligados a uma ideia de autoria cinematográfica, de cinema como arte da interpretação, mas também que era visto como uma arte que traz, como os quadros pintados, uma assinatura, pois porta uma visão de mundo que provoca interferências. Lorival Pariz, também caminhou nesse sentido, buscou interferir e deixar suas marcas pelos territórios que percorreu, pelas múltiplas artes corporais que cultivou e compartilhou. Assim, um ator que soube transitar por temas, suportes e por seu tempo.

${ }^{26}$ Fonte: https://www.facebook.com/478506518930320/photos/a.478508875596751.1073741825.478506518930320/478508878930084/?type=1\&theater 


\section{Referências}

A MORTE DE UM CAIXEIRO VIAJANTE. In: Enciclopédia Itaú Cultural de Arte e Cultura Brasileiras. São Paulo: Itaú Cultural, 2018. Disponível em: <http://enciclopedia.itaucultural.org.br/obra62907/paulo-autran-a-direita-em-cena-de-a-morte-de-um-caixeiro-viajante>. Acesso em: 13 mar. 2018. Verbete da Enciclopédia. ISBN: 978-85-7979-060-7.

ANDRADE, João Batista de. 'Dívidas, censura e como "Gamal" virou "Gamal, o Delírio do Sexo'. In: Folha de S. Paulo. São Paulo, 31/07/2016, f.5. Acessado em 24 out. 2016, disponível em: http://www1.folha.uol.com.br/ilustrissima/2016/07/1796523-dividas-censura-e-como-gamal-virou-gamal-o-delirio-do-sexo.shtml

BERNARDET, Jean-Claude. 'Cinema Novo, Anos 60-70: a questão religiosa'. In: SOSNOWSKI, Saul \& SCHWARTZ, Jorge. Brasil: o trânsito da memória. São Paulo: Edusp, 1994.

BONONI, José Gustavo. A história do teatro através da imagem fotográfica. Um olhar sobre a peça "As três irmãs" de Tchekhov, representada pelo Teatro Oficina em 1972. In: http://www.snh2011.anpuh.org/resources/anais/14/1308174305_ARQUIVO_Trabalho completoJoseGustavoBononiXXVIAnpuh.pdf. Acessado em 08 mar. 2017.

CARDOSO, Reni. Ewerton de Castro: minha vida na arte - memória e poética. São Paulo: Imprensa Oficial do Estado de São Paulo, 2009.

CHAMARELLI, Manoela Sara. Um Grito Parado no Ar (Gianfrancesco Guamieri - 1973) Imagens da Resistência Democrática no Teatro Brasileiro. Universidade Federal de Uberlândia, Monografia de Graduação em História, 2007.

DEL RIOS, Jefferson. Crítica teatral. Vol. 1. São Paulo: Imprensa Oficial do Estado de São Paulo, 2010. 316p.

DWEK, Tuna. Maria Adelaide Amaral: a emoção libertária. São Paulo: Imprensa Oficial do Estado de São Paulo: 2005, 352p.

GÓES, Marta. Regina Braga: talento é um aprendizado. São Paulo, 2008

HERNANDES, Leandro Longui. Pelas Brechas da Resistência: 'Um grito parado no ar' (1973) como exercício de um teatro de ocasião. Dissertação de Mestrado: Universidade Federal de Uberlândia: Programa de Pós-Graduação em História, 2014, 139f.

MAGALDI, Sábato. Amor ao Teatro. São Paulo: Edições Sesc, 2014.

NEGREIROS, Lizete. Centro Brasileiro de Teatro para a Infância e Juventude. In: http:// cbtij.org.br/lizette-negreiros/. Acessado em 13 mar. 2018. 
MICHALSKI, Yan. O Teatro sob Pressão. Rio de Janeiro: Jorge Zahar, 1985.

NAPOLITANO, Marcos. Cultura Brasileira - utopia e massificação (1950-1980). São Paulo: Contexto, 2001.

NEMER, Sylvia. O dragão da maldade contra o santo guerreiro: a encenação do desafio. In: HAMBURGUER, Esther et all. Estudos de Cinema Socine. São Paulo: Socine/ Annablume. 2008.

RIDENTI, Marcelo. Em busca do povo brasileiro. São Paulo: Record, 2000.

ROCHA, Eliana. Marcos Caruso: um obstinado. São Paulo: Imprensa Oficial/Col. Aplauso, 2007.

XAVIER, Ismail. Alegorias do subdesenvolvimento: cinema novo, tropicalismo e cinema marginal. São Paulo: Cosac \& Naify, 2014.

ZOO Story. In: Enciclopédia Itaú Cultural de Arte e Cultura Brasileiras. São Paulo: Itaú Cultural, 2018. Disponível em: <http:// enciclopedia. itaucultural. org.br/ evento391505/zoo-story>. Acesso em: 13 Mar. 2018. Verbete da Enciclopédia. ISBN: 978-85-7979-060-7.

Recebido em: 30/03/2018

Aprovado em: 29/06/2018 